Research.

\title{
THE INFLUENCE OF FINANCIAL RATIOS AND COMPANIES SIZE TO PREDICT CONDITIONS OF FINANCIAL DISTRESS (RESEARCHES ON COMPANIES LISTED ON INDONESIAN STOCK EXCHANGE FOR THE PERIOD 2013-2017)
}

\author{
Dahlia ${ }^{*}$ \\ 1) Universitas Binaniaga Indonesia, Bogor, Indonesia \\ 1)dahlialetter@gmail.com
}

Received: March 20, 2021; Accepted: June 10, 2021; Published: June 30, 2021

* Corresponding author

To cite this article: Dahlia,D. (2021). The influence of financial ratios and companies size to predict conditions of financial distress: researches on companies listed on indonesian stock exchange for the period 2013-2017. The Accounting Journal of BINANIAGA. 6 (1), 27-38. doi: 10.33062/ajb.v6i1.419

ABSTRACT: This research aims to determine the condition of financial distress by using the Indicator Current ratio, Debt to Equity ratio, Total Assets Turn Over and company size (SIZE) measured in the natural logarithm of Total Assets. The research period was 20132017 by dividing 2 groups of companies, namely between companies that suffered losses and companies that did not suffer losses. Data analysis, with Descriptive, Logistic Regression testing and Independent Sample $T$ test. The results of the research obtained that the hypothesis for Current ratio and SIZE does not match the results; Total Assets Turn Over affects bankruptcy and Debt to equity ratio has no effect on bankruptcy. From the different tests obtained results there are significant differences between the group of companies in financial distress conditions and companies that are safe.

Keywords: financial distress, current ratio, debt to equity ratio, total asset turn over, size, $T$-test difference test

\section{INTRODUCTION}

\section{Background}

The financial condition of the company presented in the financial statements is a source of information for economic decision making. In order for the information presented to be more useful, financial statements must be converted into useful information in economic decision making. This is done by analyzing financial statements. The model that is often used in performing such analysis is in the form of financial ratios that describe the results of activities that have been carried out.

According to Van Horne \&Machowicz (2012), the tool used to assess the financial condition and performance of the company is the financial ratio. According to Asnawi \&Wijaya (2015) the use of ratio is a financial language. Kaplan \&Atkinson (1984) stated that the use of financial and non-financial measures in measuring individual performance is very important because both measures are able to see activities that create benefits performed by individuals. Financial measures have an object that is better than non-financial measures because it has a quantitative size.

The establishment of the company generally aims to make a profit, therefore the company needs capital or funding as the basis for conducting its operations in order to create profit. Companies that go public use the existence of the capital market as a means to obtain a source of funds or alternative financing, which in the future the market

Dahlia. The influence of financial ratios and companies size to predict conditions of financial distress: researches on companies listed on indonesian stock exchange for the period 2013-2017 
will be a reflection of the company's performance and financial condition because the market will respond to all activities carried out by the company. Based on this, the number of companies that go public every year continues to increase.

This reflects the growing number of companies that use the capital market to obtain sources of funds as an alternative financing. The activities run by the company aim to earn income. Funding strategy is indispensable, relating to the results of operations in the hope that the company will generate profits and survive in the long term so that it does not undergo liquidation.

Liquidation often occurs in companies that have been operating for a certain amount of time due to the company experiencing financial difficulties due to operational losses and ending in bankruptcy. Corporate bankruptcy is a daunting thing, both for the owner of the company and the employee. However, if the creditors and investors do not get certainty about their respective funds, then decisions and withdrawals begin to be made and lead to bankruptcy.

Sindo News, on February 17, 2016 with the article title "Large companies bankrupt in Indonesia" reported that many companies are unable to survive because of mis-capture of market opportunities or mis-strategy resulting in several bankruptcies. This condition is experienced by several companies in Indonesia, including Ford Motor Indonesia, General Motor Indonesia (GMI) and Bouraq.

When the company is unable to manage its debt properly, then the biggest consequence that will face the company is that the company will experience financial difficulties that can lead to bankruptcy. Before a company is declared bankrupt, there is usually a period where the company has financial difficulties, difficulty in generating profit, or profit that continues to decline from year to year. The period is called financial distress, which usually occurs before the bankruptcy period. Analysis of the symptoms of bankruptcy should be conducted, in anticipation of the occurrence of bankruptcy in the future. The way it is done is by analyzing the financial ratios of companies with a certain model as in this research.

Financial distress is a stage of deterioration of financial condition experienced by a company, which can be detected before the occurrence of bankruptcy or liquidation. Platt \&Platt (2002), in his research found conditions that generally occur before the bankruptcy stage, among others marked by delays in delivery, declining product quality, and delays in payment of bills from banks. Thus, a company is declared bankrupt if the company is unable to fulfill its obligations to investors, which is because the company itself is experiencing financial difficulties. Financial difficulties trigger disruption of the company's operational activities so that profits tend to continue to fall, due to the emergence of additional costs, resulting in companies that can no longer afford to finance the company's operations. The existence of information about the condition of financial distress earlier can provide opportunities for management, owners, investors, regulators, and other stakeholders to make relevant efforts.

As an institution trusted by the public in facilitating and making regulations related to the Indonesian capital market, the Indonesia Stock Exchange (IDX) strives to realize an orderly, transparent, and efficient market. Therefore, the Indonesia Stock Exchange (IDX) makes regulations related to several things, including companies whose shares are traded (listing). Currently in Indonesia there is a phenomenon called delisting. Indonesia Stock Exchange (IDX) will warn up to sanctions on companies that violate the existing rules, where the toughest sanctions are abolished (delisting) from the Indonesia Stock Exchange (IDX).

Delisting can be interpreted as an action taken by the exchange authority so that the issuer's securities are no longer traded on the exchange floor. There are two forms of delisting. First, forced delisting, this form of delisting occurs when the company is no longer able to meet the criteria and conditions of listing that have been set by the stock

Dahlia. The influence of financial ratios and companies size to predict conditions of financial distress: researches on companies listed on indonesian stock exchange for the period 2013-2017 
exchange. Second, voluntary delisting mechanism, in which issuers apply to exit the exchange according to internal reasons.

The existence of a delisting company raises the assumption that the company is not able to predict or overcome financial distress conditions that lead to bankruptcy. Therefore, an early warning system is needed that is able to anticipate and identify the emergence of financial distress.

\section{Formulation of the problem}

Based on the background mentioned above, the limitations of research problems will be concentrated on the following:

1. Does current ratio affect financial distress condition in companies that have negative Earning After Tax?

2. Does Debt Equity Ratio affect financial distress conditions in companies that have negative Earning After Tax?

3. Does Total Assets turn over affect financial distress conditions in companies that have negative Earning After Tax?

4. Does SIZE affect financial distress conditions in companies that have negative Earning After Tax?

\section{Research Objectives}

Based on the formulation of the problems that have been expressed, the objectives of this research are:

1. Knowing the effect of Current Ratio on financial distress condition on companies that have negative Earning After Tax,

2. Knowing the effect of Debt Equity Ratio on financial distress conditions on companies that have Negative Earning After Tax,

3. Knowing the effect of Total Assets Turn Over Ratio on financial distress conditions in companies that have Negative Earning After Tax,

4. Knowing the influence of Size on financial distress conditions on companies that have negative Earning After Tax.

\section{REVIEW OF LITERATURE}

\section{Financial Distress}

Financial distress or financial difficulty is a condition of a company that is in the stage of declining financial performance where the company is unable to meet the company's obligations, such as bond payments, credit, or interest expense, so the company needs to take corrective steps so that the condition does not take place continuously.

The financial distress condition that is being experienced by the company will experience a decrease in the company's functions, ranging from systems, components, processes and resources that will be interconnected, so that when an error occurs, it will have an impact on the overall level in the company (Rajni Sofat and Preeti Hiro, 2012:387). Financial distress condition will certainly not only be faced by the company's management but also by shareholders, stakeholders, suppliers and creditors so that given the many impacts that will be caused by this condition, the company needs to anticipate and even avoid worse financial difficulties.

Bhattacharyya (2012:445) states distress is an acute financial difficulty or crisis. The company is experiencing difficulties or in a state of illness means that the situation of the company when it is unable to meet the debt, in other words, when the total value of

Dahlia. The influence of financial ratios and companies size to predict conditions of financial distress: researches on companies listed on indonesian stock exchange for the period 2013-2017 
the company's assets is not enough to pay the total external obligations, it can be said that the company has difficulty.Ross (2013:928) states financial distress is a situation where the company's operating cash flow is insufficient to meet its current obligations (such as trade credit or interest expense) and the company is forced to take corrective action. William H.Beaver (2012:3) states, financial distress refers to inability to pay obligations when due financial distress, refers to the company's inability to pay bonds when they are due.

Financial difficulties occur due to debt traps, due to the many thoughts that debt provides convenience.Asnawi (2015) in Investor Daily, quoted on November 12, 2015 under the title "Personal finance, debt trap" states that debt will feel burdensome if interest expense is floating and rises more often. Consequently the installments will increase. With the increase in installments, the debtor must increase his income to pay the debt installments, so as not to experience financial difficulties.

\section{Indicators of Financial Distress}

Indicators of financial distress conditions of a company can be classified depending on the area or field that can indicate the indication of the cause of financial difficulties. Bhattacharyya (2012:447) writes indicators of a company experiencing financial distress, among others in the field of operations, finance, bookkeeping and other fields, such as the decline in the value of the share price, as well as changes in management. Ekawati $(2015 ; 9.3)$ writes that financial difficulties can occur due to mistakes and weaknesses that are directly or unrelated to the company's management. Financial factors include an unbalanced capital structure (over-using debt) or insufficient amount of capital to support the company's business.

Financial difficulties begin with the company's inability to meet payment obligations on time, resulting in reduced trust of creditors, and finally no one to provide loans in the future. Signs of financial difficulty can be detected early on in a relatively long time using financial ratios, before bankruptcy.

\section{The Role of Financial Management}

Business activities run by business organizations in general is to obtain the difference between business revenues and expenses that encourage business expansion. Griffin ((2016) argues business is an organization that produces or sells goods or services for profit. Profit or benefit is always measured quantitatively. To earn profit, optimal financial arrangements are required. The science that learns about allocating limited resources in the company's business sphere is financial management.

Ekawati $(2015 ; 11)$ wrote "the main topic in financial management is how a financial manager who makes a financial decision today will affect the results and risks that the company will accept in the future". Gitman (2012; 4) states "finance can be defined as the science and art of managing money". Gitman's statement can be developed that finance as a science has an art; finance that has standard standards set by principles, concepts and theories, in practice expertise and experience are needed.

Financial managers must be able to adapt to changes, raise funds, invest in assets, and manage wisely to influence the success of company activities. The decision function in financial management can be divided into three main areas, namely investment, funding, and asset management. The results of the activities of a financial manager are stated in a report, which contains an overview of financial items obtained in one period.

\section{Financial Ratio Analysis}

Financial ratio analysis is one of the methods used to find out the various problems faced by the company. The purpose of financial ratio analysis is, among others, to make improvements to the company's bad situation that makes activities stop in the future, as well as to find out the results of the company's performance either as a whole or in detail from time to time.

Dahlia. The influence of financial ratios and companies size to predict conditions of financial distress: researches on companies listed on indonesian stock exchange for the period 2013-2017 
a. Liquidity Ratio

Liquidity Ratio is used to measure the company's ability to meet its short-term liabilities. Asnawi \& Wijaya $(2015 ; 22)$ stated that the liquidity ratio is a ratio that shows the company's ability to pay immediately (liquid) to immediate obligations. The formulation for the CR liquidity ratio can be written as follows:

$C R=\frac{\text { Current Assets }}{\text { Current Liabllities }}$

b. Financial Solvency (Leverage/Debt) Ratio

The solvency ratio shows the ability to pay for the long term. This ratio is used to be able to test the extent to which the company uses the borrowed money.

$D E R=\frac{\text { Total Liabilities }}{\text { Total Ekuitas }}$

c. Activity Ratio

In a general context, this ratio is often referred to as turnover. Total Assets Turnover (TATO), which is a ratio to measure the efficiency of the use of assets as a whole.

$$
\text { TATO }=\frac{\text { sales }}{\text { Total Assets }}
$$

d. Company Size (Firm Size)

In general, company size can be interpreted as a comparison of the size of the business on a scale where certain classifications can be made. The size of the company is measured in various ways, including: total assets at the end of the year, stock market value, number of employees, total sales, market capitalization and others. Company size can also be calculated by:

$$
\text { Size }=\text { Ln Total Assets }
$$

The purpose of using the company size parameter above is to predict financial distress conditions, on the grounds that if the number of assets decreases, there are several reasons related to the decrease in assets due to company losses, and the last resort is to use assets to fund company operations.

\section{Impact of Financial Distress Conditions for Companies}

Financial distress conditions for companies are very influential for internal and external parties. Various impacts on external parties, including creditors, investors and even the government will cause negative thoughts for the company.

The impact of financial distress conditions is also stated by Anderson (2013: 25) where according to Anderson the impact of financial distress can be divided into five levels, namely Negligible; Moderate, Severe, bankruptcy, and Survival Issues.

Dahlia. The influence of financial ratios and companies size to predict conditions of financial distress: researches on companies listed on indonesian stock exchange for the period 2013-2017 


\section{Research hypothesis}

1. Effect of CR on the probability of bankruptcy

CR is the company's ability to pay debts that must be met immediately with current assets. Companies experiencing financial difficulties do not experience the same effect as the probability of bankruptcy. CR is high, the probability of bankruptcy should be low, and vice versa, if the CR is low, the probability of bankruptcy is high.

\section{H1: CR has a negative effect on bankruptcy}

2. The effect of DER on the probability of bankruptcy

DER is the company's ability to use and utilize borrowed money. The lower this ratio, the higher the level of corporate funding provided by shareholders, and the greater the protection for creditors (margin of protection) in the event of asset depreciation or major losses.

\section{H2: DER has a positive effect on bankruptcy}

3. The effect of TATO on the probability of bankruptcy

TATO is a ratio to measure the efficiency of the use of assets as a whole. Companies that have high sales, then the probability of bankruptcy is low. Companies that are less efficient in using assets to generate sales, the lower the sales value, so the EAT value becomes negative.

H3: TATO has a negative effect on bankruptcy

4. The effect of SIZE on the probability of bankruptcy

Comparison of large or small companies is the size of the company. The scale used in this research, the company uses a size based on total assets. Companies that are liquid, are able to make efficient use of assets and can utilize their debts properly, will further reduce the chances of bankruptcy.

H4: SIZE has a negative effect on bankruptcy

\section{RESEARCH METHOD}

This research uses multivariate analysis, with more than one independent variable and one dependent variable. This research was conducted through three stages, namely descriptive statistical analysis, logistic regression analysis and the mean difference test with independent sample T test.

\section{RESULT AND DISCUSSION}

\section{Descriptive Analysis}

This analysis is the first step and to provide a description of the data being tested. Descriptive statistics are data analysis by describing or providing pictures of data that have been collected using samples and populations (Jubilee Enterprise, 2013).

Dahlia. The influence of financial ratios and companies size to predict conditions of financial distress: researches on companies listed on indonesian stock exchange for the period 2013-2017 


\section{Descriptive Statistics Test Results}

\begin{tabular}{|lrrr}
\hline $\begin{array}{c}\text { Ratio } \\
\text { Analysis }\end{array}$ & $\begin{array}{c}\text { Statistical } \\
\text { Range }\end{array}$ & $\begin{array}{c}\text { Statistical } \\
\text { Mean }\end{array}$ & \multicolumn{1}{c}{$\begin{array}{c}\text { Std } \\
\text { Dev }\end{array}$} \\
\hline CR & 118.22 & 4.6364 & 15.48 \\
\hline DER & 16.47 & 1.1197 & 2.28 \\
\hline TATO & 4.17 & 0.7797 & 0.78 \\
\hline SIZE & $50,564.76$ & $2,816.10$ & $8,904.48$ \\
\hline
\end{tabular}

The results of descriptive analysis for the measure of data concentration, obtained the mean data (average) of the current ratio value is 4.6364 which is the average value of the current ratio for CR (1) and CR (0); the mean value of the debt equity ratio of 1.1197 is the average value of DER (1) and DER (0); the mean of total assets turn over is 0.7797 which is the average of TATO (1) and TATO (0); the mean of the size value is 2.1086.1022 which is the average of SIZE (1) and SIZE (0).

The results of the analysis of the size of the data spread, namely the standard deviation or deviation of the entire variable to the average of each of these variables. The value for the standard deviation for the current ratio is 15.48036; debt to equity ratio is 2.27619; total assets turn over is 0.77858 ; and the value for size is $8,904,47916$.

\section{Logistics Regression Analysis}

Regression testing was carried out using logit regression, because there were more than 50 sample data, and previously no normality test was performed.

\section{Logistics Regression Test Results}

\begin{tabular}{lcccccc}
\hline $\begin{array}{c}\text { Ratio } \\
\text { Analysis }\end{array}$ & $\boldsymbol{\beta}$ & SE & Wald & Df & Sig & $\begin{array}{c}\text { Exp } \\
(\boldsymbol{\beta})\end{array}$ \\
CR & 0,147 & 0,06 & 6,025 & 1 & 0,01 & 1,159 \\
\hline DER & 0,013 & 0,171 & 0,006 & 1 & 0,94 & 1,013 \\
\hline TATO & - & 0,583 & 7,273 & 1 & 0,01 & 0,207 \\
\hline SIZE & 0,001 & 0,001 & 5,682 & 1 & 0,02 & 1,001 \\
\hline Constant & $-0,47$ & 0,543 & 0,008 & 1 & 0,93 & 0,954 \\
\hline
\end{tabular}

Based on the test results above, the research hypothesis test is based on the regression coefficient value of each independent variable, namely:

\section{H1: CR has a negative effect on bankruptcy}

The regression coefficient for the $\mathrm{CR}$ variable is positive, namely 0.147 with a significance value of 0.014 which is smaller than 0.05 . It can be concluded that the results are not in accordance with the hypothesis,

\section{H2: DER has a positive effect on bankruptcy}

The regression coefficient for the DER variable is positive, namely 0.013 with a significance value of 0.938 , greater than 0.05 . It can be concluded that DER has no effect on bankruptcy.

Dahlia. The influence of financial ratios and companies size to predict conditions of financial distress: researches on companies listed on indonesian stock exchange for the period 2013-2017 


\section{H3: TATO has a negative effect on bankruptcy}

The TATO regression coefficient is negative, at (-1.573) with a significance value of 0.007 , lower than 0.05 . It can be concluded that TATO has an effect on bankruptcy. A negative value indicates that TATO has a negative effect on bankruptcy.

\section{H4: SIZE has a negative effect on bankruptcy}

The regression coefficient for the SIZE variable is positive at 0.001 with a significance value of 0.017 , which is smaller than 0.05 . It can be concluded that SIZE has an effect on bankruptcy. A positive value indicates that SIZE has no negative effect on bankruptcy.

SIZE is obtained based on the natural logarithm of the total value of the company's assets. Based on this value, the company's asset value has no negative effect on bankruptcy prediction.

Based on the regression results for the liquidity ratio (CR) of $0.147(14.7 \%)$; Solvency ratio regression coefficient (DER) of $0.013(1.3 \%)$; the regression coefficient for the activity ratio (TATO) is negative, with a value $(-157.3 \%)$ and the regression coefficient for firm size (SIZE) is $0.1 \%$. The regression model equation for the probability of bankruptcy can be formed based on the test results above, namely:

Probabilitas $=-0,47+0,147 \mathrm{CR}+0,013 \mathrm{DER}-1,573 \mathrm{TATO}+0,001 \mathrm{SIZE}$

\section{Mean Value Difference Test with Independent Sample T test}

The last test was carried out to support the results of the hypothesis that had previously been made by proving whether there was a difference in the average value of the two groups of companies. The test was carried out using the independent sample $T$ test. The hypotheses made are:

a. H0: There is no difference between group 1 and group 0 companies

b. $\mathrm{H} 1$ : There is a difference between group 1 and group 0 companies

After testing, a summary of the results obtained with a $5 \%$ confidence level is presented in the table below.

T-test Different Test Results

\begin{tabular}{|c|c|c|c|}
\hline Variable & Mean & Sign & Conclusion \\
\hline $\mathrm{CR}(1)$ & 7.44 & \multirow{2}{*}{0.035} & \multirow{2}{*}{ Significant } \\
\hline $\mathrm{CR}(0)$ & 1.83 & & \\
\hline DER (1) & 0.59 & \multirow{2}{*}{0.0105} & \multirow{2}{*}{ Significant } \\
\hline $\operatorname{DER}(0)$ & 1.64 & & \\
\hline $\begin{array}{l}\text { TATO } \\
\text { (1) }\end{array}$ & 0.53 & \multirow{2}{*}{0.0005} & \multirow{2}{*}{ Significant } \\
\hline $\begin{array}{l}\text { TATO } \\
(0)\end{array}$ & 1.03 & & \\
\hline SIZE (1) & 5502.11 & \multirow{2}{*}{0.001} & \multirow{2}{*}{ Significant } \\
\hline SIZE (0) & 130.09 & & \\
\hline
\end{tabular}

Dahlia. The influence of financial ratios and companies size to predict conditions of financial distress: researches on companies listed on indonesian stock exchange for the period 2013-2017 
From all independent variables, it can be concluded that $\mathrm{HO}$ is rejected, meaning that there is a significant difference between groups of companies with negative Earning After Tax values and companies with positive Earning After Tax values.

\section{CONCLUSIONS}

Based on the formulation of the problem that has been stated previously, as well as the results of the research that have been described in the discussion and in accordance with the purpose of the hypothesis. the researchers can provide conclusions, among others:

1. The liquidity ratio variable as measured by $\mathrm{CR}$ (Current Ratio) has no effect on the opportunities for financial distress conditions.

2. The solvency ratio variable as measured by DER (Debt Equity Ratio) has no effect on opportunities for financial distress.

3. The activity ratio variable as measured by TATO (Total Asset Turn Over) has an effect on the opportunities for financial distress conditions.

4. Firm size variable (SIZE) which is measured based on the natural logarithm of total assets has an effect on the probability of financial distress.

\section{RECOMMENDATIONS}

This research certainly has several results and it is necessary to consider several considerations that aim to avoid financial distress conditions, including:

1. With the high value of the CR variable as a liquidity analysis and SIZE obtained from the total value of the company's assets, it proves that financial distress conditions cannot be predicted from the size of the company. The value of large assets has not been ensured to provide maximum results for business activities.

2. Other considerations of low current liabilities and long term liabilities further prove that the high value of the company's assets cannot result in loans from creditors or banks.

3. This research uses quantitative variables, due to the concentration on financial management. Another factor that has not been calculated as a probability condition is management policy as a qualitative variable.

4. Changes in the Rupiah exchange rate against the dollar is one of the factors that affect the probability of bankruptcy.

\section{REFERENCES}

Asnawi, S.K \& Wijaya, C (2015), Finance for non finance. Jakarta:Rajagrafindo Persada

Asnawi,S.K.(2015), Personal finance; Jebakan Utang. Investor Daily. https://investor.id/archive/personal-finance-jebakan-utang

Atkinson, et al, (2012). Management accounting information for decision making $5^{\text {th }}$ edition. Englewood Cliffs. NJ: Prentice Hall

Cinantya,I. G.A.A.P. \& Merkusiwati,N.K.L.A. (2015).Pengaruh Corporate Governance, Financial Indicators, dan Ukuran perusahaan pada financial distress; e-jurnal Akuntansi Universitas Udayana; 897-915. https://ocs.unud.ac.id/index.php/Akuntansi/article/view/10418

Dahlia. The influence of financial ratios and companies size to predict conditions of financial distress: researches on companies listed on indonesian stock exchange for the period 2013-2017 
The Accounting Journal of BINANIAGA Vol. 06, No. 01, June 2021

p-ISSN: 2527-4309, e-ISSN: 2580-1481

$5^{\text {th }}$ Accreditation Rating: January 14, 2019 - January 13, 2024

Debarshi,B. (2012).Financial statement analysis noida. Dorling Kimsdey. Licenses of Pearson Education in South Asia.

Ekananda, M. (2016).Ekonometrika dasar, Jakarta; Mitra Wacana Media

Ekananda M. (2014).Manajemen keuangan internasional. Jakarta: Universitas Terbuka

Ekawati, E.. (2011). Manajemen keuangan, Jakarta; Universitas Terbuka

Edwin, W \& Ni Ketut Rasmini. (2015), Pengaruh audit fee, Opini going Concern, financial distress, ukuran perusahaan, ukuran KAP pada pergantian auditor. e-jurnal Akuntansi Universitas Udayana, 11.3, 940-966 https://ojs.unud.ac.id/index.php/Akuntansi/article/view/13405

Ghozali, (2013).Aplikasi analisis Multivariate dengan Program IBM SPSS 21_Update PLS Regresi. Badan Penerbit UNDIP edisi VII.,https://digilib.undip.ac.id/category/buku-dosen-undip/page/3/

Griffin, Ricky W.,Ebert, Ronald J, (2016). Bisnis Jilid I, Edisi Kedelapan, Jakarta; Erlangga

Husnan.(2015). Dasar-dasar Teori Portofolio dan Analisis Sekuritas, ed. 5. Yogyakarta:UPP STIM YKPN

Imaduddin,S \& Wibowo Buddi Wibowo. (2017).Prediksi financial distress Bank Umum di Indonesia, Analisis Diskriminan dan Regresi Logistik; Jurnal Bisnis dan Manajemen Universitas Indonesia, Vol. 7(1) 27-40 doi:10.15408/ess.v7i1.4686

Koran SINDO (2016), Perusahaan Besar Bangkrut di Indonesia. Sindo News, https://ekbis.sindonews.com/berita/1085897/39/perusahaan-besar-bangkrut-diindonesia

Krisnanda,I Gede Wahyu (2016). Pengaruh financial distress, Umur perusahaan, Audit Tenure dan kompetensi Dewan Komisaris pada Kecepatan Publikasi Laporan Keuangan Tahunan.https://ocs.unud.ac.id/index.php/Akuntansi/article/view/28355

Nekhasius, A.S,Herlina, Y.R., \& Agnes, U.W. (2016), Analisis rasio Keuangan untuk memprediksi kegagalan bisnis usaha kecil, dan menengah, JBE; 152-162 No. 2 ISSN: 1412-3126 https://media.neliti.com/media/publications/76565-ID-analisisratio-keuangan-untuk-memprediks.pdf

Nurhidayah\& Rizkiyah,F (2017), Kinerja Keuangan dalam memprediksi financial distress; Jurnall JIBEKA Vol.11 No.1. doi: /10.32812/iibeka.v11i2.59

Permana,R.K.,Ahmar, N., \& Djaddang S., (2017).Prediksi Financial Distress pada perusahaan manufaktur di Bursa Efek Indonesia. http://www.lib.ui.ac.id/file?file=pdf/abstrak/id abstrak-20463047.pdf

Republik Indonesia, (2008), Undang Undang No.20 (Ukuran Perusahaan) https://peraturan.bpk.go.id/Home/Details/39653/uu-no-20-tahun-2008

Ross S.A,, Randolph, Westerfield \& Jeffrey . (2013).Corporate Finance Tenth Edition. New York: McGraw-Hill.

Rudianto.(2013). Akuntansi Manajemen Informasi untuk pengambilan Keputusan Strategis.Jakarta:Erlangga

Dahlia. The influence of financial ratios and companies size to predict conditions of financial distress: researches on companies listed on indonesian stock exchange for the period 2013-2017 
The Accounting Journal of BINANIAGA Vol. 06, No. 01, June 2021

p-ISSN: 2527-4309, e-ISSN: 2580-1481

$5^{\text {th }}$ Accreditation Rating: January 14, 2019 - January 13, 2024

Sofat, Rajni \& Preeti.(2012).Strategic Financial Management. New Delhi:PHI Learning Private Limited.

Sugiono. L.P., \& Christiawan, Y.J., (2013); Analisa Faktor Yang Mempengaruhi Likuiditas pada Industri Ritel yang Terdaftar pada Bursa Efek Indonesia Tahun 2007-2012, Jurnal Business Accounting Review, Vol.1 No.2,;298-305. https://media.neliti.com/media/publications/186595-ID-analisa-faktor-yangmempengaruhi-likuidi.pdf

Tendelilin Eduardus. (2016).Manajemen Investasi. Jakarta: Universitas Terbuka

Van Horne, J.C,\& Wachowicz, Jr. (2014). Fundamentals of financial management.NJ:

Prentice Hall

Dahlia. The influence of financial ratios and companies size to predict conditions of financial distress: researches on companies listed on indonesian stock exchange for the period 2013-2017 
The Accounting Journal of BINANIAGA Vol. 06, No. 01, June 2021

p-ISSN: 2527-4309, e-ISSN: 2580-1481

$5^{\text {th }}$ Accreditation Rating: January 14, 2019 - January 13, 2024

This page intentionally be emptied

Dahlia. The influence of financial ratios and companies size to predict conditions of financial distress: researches on companies listed on indonesian stock exchange for the period 2013-2017 